\title{
ŠVIETIMO POLITIKOS, UGDYMO KOKYBĖS IR PASLAUGŲ VARTOTOJŲ POREIKIŲ TENKINIMO SĄSAJOS
}

\author{
Dalia Martišauskienė, Kęstutis Trakšelys \\ Klaipėdos universiteto Tęstinių studijų institutas \\ Sportininkų g. 13, 92257 Klaipéda, Lietuva \\ Telefonas (8 46) 398 972, (8 46) 398765 \\ Elektroninis paštas: dalia.martisauskiene@ku.lt, kestutis.trakselys@ku.lt \\ Pateikta 2013 m. rugsejo 2 d., parengta spausdinti 2013 m. lapkričio 27 d. \\ doi:10.13165/SMS-13-5-4-11
}

\begin{abstract}
Anotacija. Straipsnyje nagrinejjama, kodèl Lietuvoje iki šiol pasigendama dermès tarp formuojamos valstybinès, regioninès švietimo politikos teikiamu paslaugu kokybès bei vartotoju poreikių tenkinimo, norint garantuoti vaikui galimybę pasinaudoti valstybès teikiamomis paslaugomis.

Pristatomi empirinio tyrimo duomenys, kurie atskleide, jog ugdymo istaiga, siekdama teikti kokybiškas paslaugas, turi identifikuoti skirtingus tèvu (grupinius ir individualius) poreikius, lükesčius, dalyvavimo patirtí, vertybes bei ịtraukti juos $i$ ugdomosios veiklos ir istaigos kūrimą, motyvuoti bendradarbiavima su ugdymo paslaugu teikèjais.
\end{abstract}

Reikšminiai žodžiai: švietimo politika, ugdymo kokybė, paslaugų vartotojų poreikių tenkinimas.

Socialinių mokslų studijos / Societal Studies

(C) Mykolo Romerio universitetas, 2013

(C) Mykolas Romeris University, 2013
ISSN 2029-2236 (print), ISSN 2029-2244 (online) http://www.mruni.eu/lt/mokslo_darbai/SMS/ http://www.mruni.eu/en/mokslo_darbai/SMS/ 


\section{Ivadas}

Kaita, kaip vienas iš esminių postmodernistinès visuomenès bruožų ${ }^{1}$, neišvengiamai veikia politinius pokyčius švietimo srityje, o nè vienas svarbesnis pokytis viršutiniojoje švietimo grandyje neaplenkia ir ugdymo institucijų, kurios yra nuolatinès kaitos būsenos ${ }^{2,3}$. Todèl šiandieniniame pasaulyje kaita tampa îprastu ir nuolatiniu reiškiniu, kurio sklaidoje švietimas siejamas su atvira pokyčiams, dinamiška, mobilia, prisitaikančia ugdymo sistema. Mokslininkų ${ }^{4,5,6}$ nuomone, dažniausiai ir visuomenès augimas bei individo gyvenimo perspektyvos priklauso nuo švietimo kokybės ir švietimo politikos.

Švietimo kokybė ir edukacinių bei socialinių paslaugų teikimo efektyvumas, kaip minèta, neatsiejama švietimo politikos dalis. Švietimo politika - tai viena iš viešosios politikos sričių. Kintant viešajai politikai, paprastai reformos vyksta ir švietime. Švietimo politikos strategija yra apibūdinama kaip politikos priėmimas ir jos keitimo procesas, kuriuo siekiama reaguoti $i \mathfrak{k}$ kintantị švietimo kontekstą ${ }^{7}$. Švietimo politika visų pirma yra susijusi su instituciniais švietimo aspektais: įstatymais, reglamentais ir kolektyvinemis jų igyvendinimo priemonèmis (ịstaigomis, jų struktūra ir ryšiais, programomis ir instrukcijomis, valdininkais ir hierarchija, biudžetu $)^{8}$. Švietimo politika yra viešojo sektoriaus, kuris teikia viešąsias gèrybes ir paslaugas, vadovaudamasis viešuoju interesu, politika arba visuomenès švietimo būklę lemiantys valdžios institucijų sprendimai ir su jais susiję veiksmai9, 10 . Ji gali būti tarptautinè, nacionalinė, regioninè. Galime kalbèti apie šalies švietimo politiką tik tuo atveju, jei švietimas priklauso nuo valstybès, nesvarbu, ar valstybẻ yra centralizuota, ar regiono, komunos lygiu politiškai organizuotos bendruomenès ar asociacijos. Švietejjišką veiksmą charakterizuojančių duomenų visuma turi būti kolektyviai ir aiškiai suformuluota. Švietimo politika atsiranda, kai yra institucija. Tai yra organizuota bendruomenė ir aiškiai apibrèžti dokumentai, reguliuojantys mokyklos ar mokyklų visumos funkcionavimo sąlygas.

Taigi, šiuolaikiné Lietuvos švietimo politika reikalauja garantuoti mokiniui galimybe pasinaudoti valstybés teikiamomis paslaugomis, kurti ịvairesnes vaikų ir jaunimo porei-

1 Fullan, M. Innovation, Reform and Restructuring Strategies. Cawelti, G. (ed) Challenges and Achievement of american Education. New York: ASCD, 1993.

2 Bulajeva, T., et al. Lietuvos švietimo politikos transformacija. Vilnius: Vilniaus universiteto leidykla, 2009.

3 Hargreaves, A.; Reynolds, D. Decomprehensivization. Hargreaves, A. (eds) Education Policies: Controversies and Critiques. Philadelphia: The Falmer Press, 1989.

4 Vaicekauskienè, V. Švietimo politikos analizés pagrindai. Vilnius: Švietimo ir mokslo ministerija, 2007.

5 Vaicekauskienè, V. Specialiuju poreikiu vaiku socializacija. Vilnius: Vilniaus universiteto leidykla, 2005.

6 Trowler, P. Education Policy. Second edition. London and New York: Routledge, 2003.

7 Bulajeva, T., et al., supra note 2.

8 Andriekienè, R. M.; Anužienè, B. Andragoginiai kompetencijų tobulinimo aspektai tęstiniame profesiniame mokyme. Klaipeda: Klaipedos universiteto leidykla, 2006.

9 Vaicekauskienè, V. Švietimo politikos analizès pagrindai, supra note 4.

10 Vaicekauskienè, V. Specialiuju poreikiu vaiku socializacija, supra note 5. 
kius atliepiančias ugdymo ir socialinių paslaugų formas. Ugdymo institucijų, kaip ir kitų organizacijų, veiklos tikslas - vartotojų poreikių tenkinimas, todèl svarbu įsisąmoninti, kad vartotojai yra svarbiausi asmenys, nes ne vartotojai priklauso nuo įstaigos, bet įstaiga priklauso nuo jų. Kitaip tariant, ne organizacija teikia paslaugą besikreipiantiems, bet jie suteikia paslaugą i̇staigai, kai ji juos aptarnauja ${ }^{11,12}$.

Vertinant švietimo paslaugas, vartotoju požiūriai ir lükesčiai skiriasi, nes kiekvienas vartotojas savitas, todèl jo poreikiai, žinios, vertybès ir naudotini igūdžiai taip pat nèra identiški. Ugdymo įstaigos vartotojai yra vaikai, lankantys mokyklą, taip pat ir jų tèvai, todèl, teikdama švietimo ir socialines paslaugas, švietimo institucija turi atsižvelgti būtent i jų poreikius. Tinkamas vartotojų poreikių identifikavimas ir jų ịtraukimas ị ugdomosios veiklos bei ugdymo institucijos strateginių planų rengimą ir igyvendinimą, igalina efektyviau bendradarbiauti su paslaugos gavejjais. Ugdymo įstaiga, siekdama igyvendinti valstybinę, regioninę švietimo politiką, identifikuoti savo paslaugų vartotojų poreikius, turi įvertinti švietimo politikų, paslaugų atlikejjų ir vartotojų lūkesčius, tikslus bei siekius.

Taigi ugdymo istaigos turi gebèti ne tik vykdyti valstybinę, regioninę švietimo politi$k a$, bet ir sudaryti palankias ir tinkamas sąlygas vaiku ugdymuisi, socializacijai, o kartu ir vartotojų ugdymuisi ${ }^{13,14}$. Švietimo paslaugų poreikis ir kokybe் - tai objektyvių sąlygų, aplinkybių nulemta vartotojų būklè, situacija, kai jiems reikia tokių socialinių / edukacinių paslaugų, kurios būtų kokybiškos ir orientuotos ị vartotojų lūkesčius, kurios padètų igyvendinti vartotojų pageidavimus ir galimybes, atlieptų laikmečio aktualijas bei padètų spręsti kylančias problemas ${ }^{15,16}$.

Ugdymo ịstaigu praktika rodo, kad tinkamas paslaugų vartotojų poreikių tyrimas tiesiogiai turi ịtakos jos kokybès valdymo sistemai ir ugdymui. Todèl, vertinant ugdymo isstaigų teikiamų paslaugų kokybę, dažniausiai remiamasi paslaugų gavejjo, kaip vartotojo, kokybès vertinimu. Mokslininkai ${ }^{17}$ išskiria tokius paslaugų kokybės vertinimo vartotojo požiūriu aspektus:

- $\quad$ paslaugu gavejas kaip vartotojas. Svarbu užtikrinti teikiamos paslaugos individualumą, kadangi visų paslaugų vartojimas yra individualus procesas;

- $\quad$ paslaugų gavejas kaip pilietis, tam tikros tautybès žmogus. Svarbu nepažeisti vartotojo, kaip piliečio, tam tikros tautybès atstovo, interesų, teisių, orumo;

11 Išoraitè, M. Socialiniu paslaugu administravimas. Vilnius: Saulelè, 2007.

12 Išoraite, M. Veiklos rezultatyvumo vertinimo ypatumai švietimo institucijose. Ekonomika ir vadyba: aktualijos ir perspektyvos. 2005, 5: 135-143.

13 Trakšelys, K.; Martišauskienè, D. Pedagogų profesionalizacijos aspektai modernioje visuomenèje. Tiltai. 2013, 2 (63): 141-159.

14 Šimanskienè, L.; Trakšelys, K. Pedagoginès psichologinès pagalbos teikimas Lietuvos ir JAV švietimo sistemoje. Socialinis darbas. 2009, 8 (2): 75-85.

15 Trakšelys, K. Mokinių edukacinio stimulo deficitas. Tiltai. 2008, 2: 61-73.

16 Chreptavičienė, V. Dalykinès komunikacijos raštu mokẻjimų samprata, lygiai. Edukologijos idejos Lietuvos švietimo sistemos modernizavimui (sudaryt. P. Jucevičienè). Kaunas: Technologija, 1998.

17 Žalimienè, L. Socialinès paslaugos. Vilnius: Vilniaus universiteto Specialiosios psichologijos laboratorija, 2003. 
- $\quad$ paslaugu gavėjas kaip konkrečios bendruomenės narys. Svarbu nepamiršti, kad kiekvienas vartotojas yra tam tikros bendruomenès narys, tad svarbūs ir jo interesai, ir poreikiai. Be to, tai susiję su paslaugų tinklo teritorinio išdèstymo klausimais ir principais, nes kiekviena paslaugos sritis turi savo paslaugų ịstaigu teritorinio išdèstymo principus, kuriuos lemia tos paslaugos specifika, teritorijų planavimas, plètojimas ir t. t.;

- $\quad$ paslaugų kokybė gali būti vertinama kiekybiniais ir kokybiniais rodikliais, kurie ypač svarbūs ugdymo įstaigų teikiamų paslaugų vertinimui. Dažniausiai taikomi tokie socialinių ir švietimo paslaugų kokybès vertinimo būdai: pagal nustatytas ir patvirtintas paslaugų charakteristikas, standartus; pagal klientų vertinimus: ką jie mano apie gaunamas paslaugas, ar patenkinami jų lūkesčiai, ko jie tikejjosi gauti ir ką gavo; pagal kitų šalių paslaugų teikèjų patirtį.

Visapusiška paslaugų kokybė vertinama visais trimis minėtais metodais, tačiau švietimo kontekste tiek teikiamų paslaugų kokybės vertinimas, tiek šios kokybės užtikrinimas turi būti suvokiamas ir kaip vartojimas, ir kaip investavimas. I. Mačerinskiené ${ }^{18}$, remdamasi Schultzu, pabrèžia būtent tokị požiūrị ị švietimą (žr. 1 pav.).

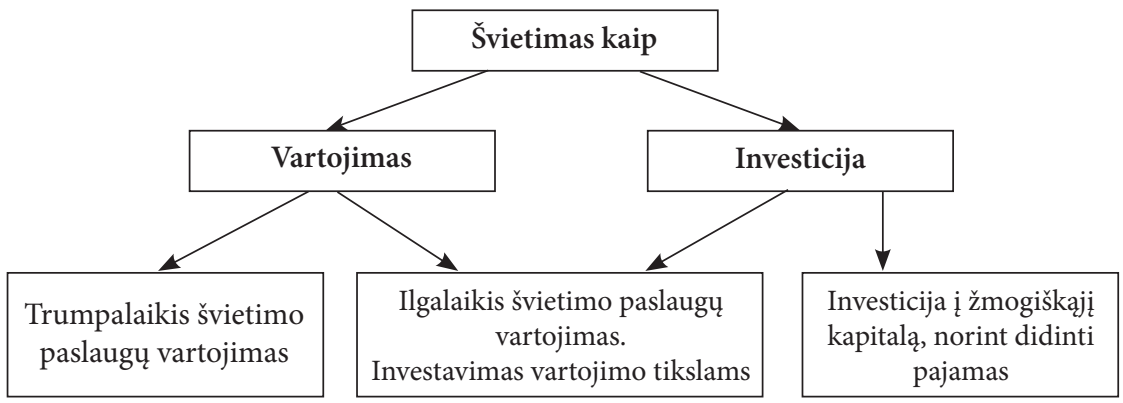

1 pav. Švietimas kaip vartojimas ir kaip investicija (I. Mačerinskienė, 1998, p. 69)

Kaip teigiama mokslinejje literatūroje ${ }^{19}$, vartojimo komponentai gali būti trumpalaikio ir ilgalaikio vartojimo. Ilgalaikiam vartojimui priklauso investicijos, kurios tarnauja būsimam vartotojui ateityje, o investicijos siaurąja prasme apima tik tas investicijas, kurios per švietimo efektą veikia ateities pajamų augimą.

Visgi švietimo organizacijų interesai turi pakilti virš finansinės ar ekonominès naudos, nes jų veiklos rezultatas yra ne prekè ir ne vienkartinė paslauga, o išsilavinęs žmogus ir pagrindinio paslaugų vartotojo - vaiko / jaunuolio ir jo tėvų - interesų patenkinimas bei

18 Mačerinskiené, I. Švietimo paslauga vartojimo ir investavimo ị žmogiškąji kapitalą aspektu. Edukologijos idèjos Lietuvos švietimo sistemos modernizavimui (sudryt. P. Jucevičienè). Kaunas: Technologija, 1998.

Ibid. 
tinkamas poreikių nustatymas. Todèl anot R. Želvio ${ }^{20}$, per pastarąji dešimtmetį vis labiau atsižvelgiama ị konkrečias besimokančiųjų - specialių poreikių vaikų, gabių vaikų ir kt. reikmes, idant geriau galètų tenkinti vaikų / jaunuolių individualius poreikius, nors bene mažiausiai praktikuojamas tėvų, bendruomenès, darbdavių ir kitų suinteresuotų grupių susitarimas. Tai atskleidžia, kad pagal tai, kuriam vartotojui teikiama pirmenybé, švietimo paslaugų teikèjų požiūris ị kokybę gali gerokai skirtis. Mokslinejje literatūroje ${ }^{21},{ }^{22},{ }^{23}$ švietimo kokybė gali būti apibrèžiama trejopai:

- $\quad$ ekspertų nustatytu kokybès standartu;

- $\quad$ sutikimu su susitarimo nustatytais kriterijais (pvz., tèvų komiteto ir mokyklos susitarimas dèl teikiamų paslaugų);

- $\quad$ individualaus vartotojo poreikių patenkinimu, t. y. atsižvelgimu ị konkrečias kiekvieno besimokančiojo reikmes.

Pirmu atveju svarbiausiu vartotoju švietimo paslaugų teikèjai laiko valstybę, antru bendruomenès ir tèvų asociacijas, o kartais profesines grupes ir darbdavius, trečiu - besimokančiuosius ir jų tèvus. Kol kas švietimo paslaugų teikejjai labiausiai linkę paisyti ekspertų nustatytų kokybės standartų, todèl kokybiškas ugdymas dažniausiai suprantamas kaip toks, kuris atitinka švietimo standartus.

Pasak Setery ${ }^{24}$, tokia organizacija, kuri pagrindiniu švietimo paslaugų vartotoju laiko valstybę, vadinama didelių rezultatų siekiančia ugdymo ịstaiga, o kokybiška ugdymo isstaiga yra ta, kuri vartotojais visų pirma laiko vaikus ir jų tėvus. Be abejo, ịtakingiausia vartotoja valstybinio švietimo sektoriuje išlieka valstybė, nes ji gali panaudoti tokius galingus svertus, kaip darbuotojų atlyginimų diferencijavimas pagal pasiektus rezultatus, inspektavimas, darbuotojų atestavimas, ìstaigų akreditavimas ir kt. Tačiau bendrojo ugdymo mokykla, kaip ir kiekviena kita kokybiška organizacija, siekia gerų, t. y. atitinkančių vartotojų poreikius tikslų.

Ugdymo institucijoje vartotojas yra vaikas, jo tèvai arba, kitaip tariant, - šeima, kuri gali orientuoti vaiko / jaunuolio elgseną, remdamiesi religija, politika, ekonomika, asmeninėmis ambicijomis, meile ir t. t. Šeima suformuoja vertybių sistemą, kultūrą, joje vaikai sužino savo socialinę klasę, išmoksta sukurti mokymosi, pažinimo aplinką, susiformuoti savo vaidmenị visuomeniniame gyvenime. Vadinasi, jau šeimoje susiformuoja tam tikras vaiko / jaunuolio, kaip vartotojo, elgesys, todèl pastaruoju metu šeima vis dažniau ịvardijama kaip atskiras vartotojo elgsenos formavimo ir vartojimo vienetas.

Tyrimo objektas - švietimo politikos, ugdymo kokybės ir paslaugų vartotojų poreikių tenkinimo tarpusavio sąsajos.

20 Želvys, R. Švietimo sistemos tobulinimas, gamintojai, vartotojai, teikejjai ir švietimo paslaugu kokybe. Acta Paedagogica Vilnensia. 2002, 9: 303-310.

21 Rado, P. Transition in Education. Budapest: open Society Institute, 2001.

22 Andriekiene, R. M.; Trakšelys, K. Andragogical approaches of parental education in modern society. Journal of Modern Science. 2012 , 3 (15): 127-140.

23 Trakšelys, K. Pedagogų kvalifikacijos tobulinimas: profesionalizacijos elementas. Andragogika. 2011, 1: 38-45.

Želvys, R., supra note 22. 
Tyrimo tikslas - išryškinti švietimo politikos, teikiamų ugdymo paslaugų ir vartotojų poreikių tenkinimo sąsajas.

Tyrimo metodika ir organizavimas - taikyti mokslinès literatūros analizès ir anketinès apklausos tyrimo metodai. Kiekybiniame tyrime dalyvavo 1 tiriamųjų grupè: tèvai, kurių vaikai lanko bendrojo ugdymo mokyklas. Apklausos instrumentas - klausimynas buvo konstruojamas remiantis mokslinès literatūros analize ir praktine darbo patirtimi. Klausimyną tèvams, kurių vaikai lanko bendrojo ugdymo mokyklas, sudarè šios strukturines dalys:

- laiškas tèvams,

- instrukcija,

- 4 diagnostiniai blokai klausimų: kokybės samprata, kokybei būdingi bruožai, edukacinių, socialinių ir kitų teikiamų paslaugų kokybès vertinimas.

Pasirinktas penkių balų skalès atsakymų formatas. Atsakymų pasirinkimas apima vertinimo pakopas nuo visiškai sutinku iki visiškai nežinau.

Kiekybinè anketinès apklausos duomenų matematinè statistinė analizè atlikta SPSS 16 for Windows (Statistical Package for Social Sciences) programine ịranga. Kiekybiniame tyrime taikytas aprašomasis ir daugiamatis statistikos metodas - faktorinè analizė.

Aprašomosios statistikos pagrindu atliktas pirminis kiekybinių duomenų apdorojimas, apskaičiuojant vidurkius, modą, standartinius nuokrypius, procentines išraiš$\operatorname{kas}^{25,26,27}$.

Tyrimo kintamųjų vidinė struktūra tirta faktorinès analizės metodu. Faktorinè analizė taikyta norint sumažinti tyrimo pirminių kintamųjų skaičių ir sudaryti naujas skales, leidžiančias minimaliai prarandant informacijos pakeisti charakterizuojančių požymių aibę kelių faktorių rinkiniu ${ }^{28}$.

Tyrimo imtis ir demografines charakteristikos - tyrime dalyvavo Klaipėdos regiono tèvai, kurių vaikai lanko bendrojo ugdymo mokyklas. Visa tyrimo imtis 400 respondentų.

Klaipėdos regiono tèvų, kurių vaikai lanko bendrojo ugdymo mokyklas, demografines charakteristikas atskleidžia jų amžius, išsilavinimas, gyvenamoji vieta, šeiminė bei socialinè padètis (žr. 1 lentelę).

Tyrimo dalyvių demografiniai amžiaus duomenys parodė, kad dauguma apklausoje dalyvavusių tėvų amžius 26-35 metai (56,7 proc.). Didžioji dauguma tyrime dalyvavusiųjų tẻvų yra igiję bakalauro laipsnị (69,1 proc.). Daugiausia dalyvavusiųjų tyrime gyvena mieste ( 88,5 proc.). Didžioji dauguma tėvų ( 89,7 proc.) gyvena santuokoje bei dirba tarnautojais $(62,4$ proc.).

25 Merkys, G. Testavimas - socialinių mokslų principas. Metodologinio diskurso projekcija. Socialiniai mokslai. 1999, 2 (19): 7-22.

26 Kardelis, K. Moksliniu tyrimu metodologija ir metodai. Kaunas: Judex, 2002.

27 Bitinas, B. Pedagogines diagnostikos pagrindai. Vilnius: Vilniaus pedagoginio universiteto leidykla, 2002.

28 Čekanavičius, V.; Murauskas, G. Statistika ir jos taikymai. II d. Vilnius: TEV, 2002. 
1 lentele. Tyrimo dalyvių demografiniai duomenys (proc.)

\begin{tabular}{|c|c|c|c|c|c|c|c|}
\hline \multicolumn{8}{|c|}{ Tẻvai (iš viso 400 tiriamųjų ) } \\
\hline \multicolumn{8}{|c|}{ Amžius } \\
\hline Iki $18 \mathrm{~m}$. & $19-25 \mathrm{~m}$. & \multicolumn{2}{|c|}{$26-35 \mathrm{~m}$} & $36-45 \mathrm{~m}$. & \multicolumn{2}{|c|}{$46-55 \mathrm{~m}}$. & 56 ir daugiau $\mathrm{m}$. \\
\hline 0,0 & 0,0 & \multicolumn{2}{|l|}{56,7} & 30,6 & \multicolumn{2}{|c|}{4,2} & 8,5 \\
\hline \multicolumn{8}{|c|}{ Išsilavinimas } \\
\hline \multicolumn{2}{|c|}{ Vidurinis } & \multicolumn{3}{|c|}{ Aukštesnysis } & \multicolumn{3}{|c|}{ Aukštasis } \\
\hline \multicolumn{2}{|c|}{9,7} & \multicolumn{3}{|c|}{21,2} & \multicolumn{3}{|r|}{69,1} \\
\hline \multicolumn{8}{|c|}{ Gyvenamoji vieta } \\
\hline \multicolumn{2}{|c|}{ Miestas } & \multicolumn{3}{|c|}{ Rajonas } & \multicolumn{3}{|c|}{ Kaimas } \\
\hline \multicolumn{2}{|c|}{88,5} & \multicolumn{3}{|c|}{7,6} & \multicolumn{3}{|r|}{3,9} \\
\hline \multicolumn{8}{|c|}{ Šeiminè padètis } \\
\hline \multicolumn{2}{|c|}{ Vedęs (ištekèjusi) } & \multirow{2}{*}{\multicolumn{2}{|c|}{ Nevedęs (neištekejjusi) }} & \multicolumn{2}{|c|}{ Našlys (našlè) } & \multicolumn{2}{|c|}{ Išsiskyręs (išsiskyrusi) } \\
\hline \multicolumn{2}{|c|}{89,7} & & & \multicolumn{2}{|c|}{0,6} & \multicolumn{2}{|r|}{4,8} \\
\hline \multicolumn{8}{|c|}{ Socialinè padètis } \\
\hline \multicolumn{2}{|c|}{ Bedarbis } & Darbininkas & \multicolumn{2}{|c|}{ Tarnautojas } & \multicolumn{2}{|c|}{ Verslininkas } & Kita \\
\hline \multicolumn{2}{|c|}{5,8} & 17,0 & \multicolumn{2}{|c|}{62,4} & \multicolumn{2}{|c|}{3,6} & 11,2 \\
\hline
\end{tabular}

\section{Tyrimo rezultatai}

Ugdymo įstaigos, plètodamos socialines-edukacines tèvų paslaugas, sujungia šeimą ir pedagogų bendruomenes. Tèvams yra sudaromos galimybès praktiškai dalyvauti modernizuojant ugdymą, todèl, pasak A. Juodaitytės ${ }^{29}$, naujoji tèvų švietimo ideologija yra palaikoma tam tikrais būdais: sudaromos suinteresuotųjų grupès ir joms siūlomos neformalaus švietimo programos, kurios išreiškia bendrąsias visuomenès švietimo kaitos idejjas, o ypač nuolatinio, nenutrūkstamo mokymo(si).

Ugdymo įstaigoje teikiamos ugdymo ir kitos paslaugos bei užtikrinama ju kokybe. Šiuolaikinè Lietuvos švietimo ir ugdymo politika reikalauja garantuoti vaikui ir jo šeimai galimybę pasinaudoti valstybės teikiamomis paslaugomis, kurti ịvairesnes, tėvų ir vaikų poreikius atliepiančias ugdymo ir socialinių paslaugų formas, ieškoti ịvairių finansinès paramos nedideles pajamas turinčioms šeimoms modelių ir kt. Vertinant ugdymo paslaugas ir jų kokybę, tėvams / globejjams buvo nurodyta pateikti savo nuomonę apie kokybès sampratą, kokie kokybei būdingi bruožai, apibūdinti, nuo ko priklauso teikiamų edukacinių, socialinių, informacinių-komunikacinių, kultūrinių paslaugų kokybẻ bei profesionali specializuota pagalba. Tèvų nuomonè apie kokybės sampratą pateikta 2 lentelèje.

29 Juodaitytè, A. Ikimokyklinio ugdymo sistemine kaita Europos Bendrijos ir pokomunistinèse šalyse. Acta Paedagogica Vilnensia. 2001, 8. 
2 lentelè. Kokybès samprata tèvų požiūriu ( proc.)

\begin{tabular}{|l|c|c|c|c|c|}
\hline Teiginiai & $\begin{array}{l}\text { Visiškai } \\
\text { sutinku }\end{array}$ & Sutinku & $\begin{array}{l}\text { Iš dalies } \\
\text { sutinku }\end{array}$ & $\begin{array}{l}\text { Nesu- } \\
\text { tinku }\end{array}$ & Nežinau \\
\hline Kokybe் - tai atitiktis tikslui & 49,8 & 29,9 & 20,3 & & \\
\hline Klaidų nebuvimas & 9,8 & 80,2 & 10,0 & & \\
\hline Vartotojų poreikių tenkinimas & 29,9 & 50,2 & 19,9 & & \\
\hline Paslaugos išskirtinumas & 29,9 & 39,9 & 10,3 & 19,9 & \\
\hline Tobulumas & 39,9 & 29,9 & 20,2 & 10,0 & \\
\hline Ekonominis paslaugos naudingumas & 29,9 & 29,9 & 20,2 & 9,9 & 10,1 \\
\hline Ugdymo paslaugos pokyčiai & 19,9 & 29,9 & 40,2 & 10,0 & \\
\hline $\begin{array}{l}\text { Ugdymo paslaugų atitiktis reikalavimams / } \\
\text { standartams }\end{array}$ & 59,8 & 20,2 & 9,9 & & 10,1 \\
\hline Nuolatinis ugdymo paslaugų gerinimas & 49,8 & 19,9 & 20,2 & & 10,0 \\
\hline
\end{tabular}

Apibendrinat respondentų nuomonę ugdymo paslaugų kokybès požiūriu, galima konstatuoti, jog didžioji dalis tiriamųjų teigia, kad kokybė yra atitiktis tikslui (79,7 proc.), klaidų nebuvimas darbe (90,0 proc.), 80,0 proc. vis dèlto akcentuoja, jog kokybè tai atitiktis standartams ir reikalavimams. Pusė respondentų (49,8 proc.) nurodo, jog svarbūs yra paslaugos pokyčiai. 19,9 proc. tèvų nepritaria nuomonei, kad paslaugos turètų būti išskirtinès. Galima prielaida, jog tèvai apibūdindami kokybę pirmenybę teikia ugdymo atitikimui reikalavimus, standartus, todèl galima konstatuoti, jog valstybès švietimo politikos formavimas ugdymo srityje yra labai svarbus, nes nuo pateiktų bendrų reikalavimų ugdymo programoms, standartams priklauso ugdymo kokybė mokykloje ir požiūris ị kokybę. Aktualu ne tik pateikta tèvų samprata apie kokybę, bet ir jų nuomoné apie kokybės požymius ugdymo ịstaigose. Rezultatai pateikti 3 lentelèje.

3 lentelè. Ugdymo ịstaigos kokybei būdingi požymiai (proc.)

\begin{tabular}{|l|c|c|c|c|l|}
\hline Teiginiai & $\begin{array}{c}\text { Visiškai } \\
\text { sutinku }\end{array}$ & Sutinku & $\begin{array}{c}\text { Iš dalies } \\
\text { sutinku }\end{array}$ & $\begin{array}{c}\text { Nesu- } \\
\text { tinku }\end{array}$ & Nežinau \\
\hline $\begin{array}{l}\text { Nepriekaištingas darbuotojų pareigų } \\
\text { atlikimas }\end{array}$ & 49,8 & 40,2 & 10,0 & & \\
\hline $\begin{array}{l}\text { Veiklos atitiktis nustatytiems reikalavi- } \\
\text { mams }\end{array}$ & 39,9 & 50,2 & 10,0 & & \\
\hline $\begin{array}{l}\text { Išteklių (finansinių, materialinių ir } \\
\text { žmogiškųų) racionalus panaudojimas }\end{array}$ & 59,8 & 20,2 & 19,9 & & \\
\hline $\begin{array}{l}\text { Kokybiškas savo paskirties ir misijos } \\
\text { realizavimas }\end{array}$ & 39,9 & 40,2 & 19,9 & & \\
\hline Klientų poreikių ir lūkesčių patenkinimas & 1,9 & 50,2 & 29,9 & & \\
\hline Nuolatinis vaiko ugdymo tobulinimas & 49,8 & 40,2 & 10,0 & & \\
\hline $\begin{array}{l}\text { Griežtai reglamentuota, dokumentuota, } \\
\text { kontroliuojama sistema }\end{array}$ & 19,9 & 29,9 & 30,2 & 19,9 & \\
\hline
\end{tabular}


Apibendrinat tiriamųjų požiūrị i kokybei būdingus bruožus, galima konstatuoti, jog daugumai tèvų svarbūs kokybès bruožai yra nepriekaištingas pareigų atlikimas (90,0 proc.), veiklos atitiktis numatytiems reikalavimas (90,1 proc.), žmogiškujų ir materialiųjų išteklių racionalus valdymas (80,0 proc.), klientų poreikių ir lūkesčių patenkinimas (70,1 proc.), nuolatinis ugdymo tobulinimas (90,0 proc.). Tačiau griežtai reglamentuota, dokumentuota, kontroliuojama sistema nèra priskiriama prie kokybei būdingu bruožų, šiai nuostatai pritaria tik 49,8 proc. tiriamųjų.

Kompleksines pagalbos vaikui ir jo šeimai principas ịpareigoja ugdymo ịstaigą derinti paslaugų teikimo kompleksiškumą ir skirti demesị ne tik edukacinèms paslaugoms, bet ir plètoti aktyvios socialinès paramos šeimoms politiką, stiprinant veiksmingą socioedukacinę pagalbą vaikams ir jų tẻvams, skatinančią jų motyvaciją ir atsakomybę, glaudžią socialinę partnerystę su ugdymo įstaigomis bei padedančią ịveikti socialinę atskirtị.

Vertinant teikiamų socialinių paslaugų kokybę tèvų požiūriu, faktorinès analizès pagrindinių komponenčių metodu buvo išskirti du faktoriai: socialine parama ir vaiko priežiūra (52,7 proc. atsakymų sklaidos) bei vaiku sveikatinimas ir teisių apsauga (33,2 proc. atsakymų sklaidos) (žr. 4 lentelę).

4 lentele. Ugdymo įstaigoje teikiamų socialinių paslaugų kokybės vertinimo faktorinè analizė (tèvų požiūris)

$$
(\mathrm{N}=400 ; \mathrm{KMO}=0,92 ; \alpha=0,85)
$$

\begin{tabular}{|c|c|c|}
\hline Faktoriai & $\begin{array}{l}\text { Faktorinis svoris } \\
\text { (L) }\end{array}$ & $\begin{array}{l}\text { Aprašomoji } \\
\text { sklaida (\%) }\end{array}$ \\
\hline \multicolumn{3}{|l|}{ Socialinė parama ir vaiko priežiūra } \\
\hline Specialiųjų poreikių vaikų ugdymas & 0,968 & \multirow{4}{*}{52,7} \\
\hline Socialinès atskirties integracija & 0,968 & \\
\hline Maitinimas & 0,910 & \\
\hline Vaiko globa ir priežiūra & 0,883 & \\
\hline \multicolumn{3}{|l|}{ Vaikų sveikatinimas ir teisių apsauga } \\
\hline Vaikų sveikatinimas & 0,935 & \multirow{3}{*}{33,2} \\
\hline Vaikų teisių apsauga & 0,832 & \\
\hline Sveikos gyvensenos ugdymas & 0,823 & \\
\hline
\end{tabular}

Faktorinès analizès rezultatai rodo, jog tèvų nuomone, kokybiškiausios ugdymo ịstaigoje socialinès paslaugos yra: specialiųjų poreikių vaikų ugdymas $(\mathrm{L}=0,968)$, socialinès atskirties integracija $(L=0,968)$, maitinimas $(L=0,910)$ bei vaiko globos ir priežiūros $(\mathrm{L}=0,883)$.

Antrasis faktorius - vaiku sveikatinimas ir teisiu apsauga - atskleidžia, kad tèvai taip pat akcentuoja vaikų sveikatinimo paslaugas $(L=0,935)$, vaikų teisių apsaugą $(L=0,832)$ bei sveikos gyvensenos ugdymą $(\mathrm{L}=0,823)$.

Šių dienų šeimos informuojamos ir konsultuojamos kol kas per mažai, stokojama informacijos apie teikiamas ugdymo paslaugas, ypač kaimo vietovèse. Šeimos, neturèdamos informacijos, negali pasinaudoti jau esamomis ugdymo galimybėmis, todèl valstybejje pradèta steigti daugiafunkcinius centrus, diegti naujus švietimo pagalbos teikimo mode- 
lius, siekiant patenkinti visuomenès informacinius poreikius. Tai atskleidžia, kad ugdymo institucijose reikšmingos tampa informacinès-komunikacinès paslaugos, kurios igalina glaudesnị šeimų ir ugdymo institucijų bendravimą bei bendradarbiavimą, užtikrina efektyvesnị tèvų ịsitraukimą ị vaikų darželių veiklas ir vaikų ugdymo(si) procesus.

Remiantis ugdymo paslaugų vartotojų (tèvų / globejjų) požiūriu, faktorinès analizès pagrindinių komponenčių metodu buvo išskirtas vienas informacines-komunikacines paslaugas ir jų kokybę apibūdinantis faktorius - informacinés-komunikacinès paslaugos (87,8 proc. atsakymų sklaidos). Kayserio-Meyerio-Olkino (KMO) mato dydis $\mathrm{KMO}=0,95$ atskleidžia, kad duomenys puikiai tinka faktorinei analizei atlikti. Faktoriaus vidine konsistencija $\alpha=0,95$ rodo labai aukštą teiginių vidinị susietumą ir nurodo, kad teiginiai, sudarantys faktorių, yra homogeniški (žr. 5 lentelę).

5 lentele. Ugdymo įstaigoje teikiamų informacinių-komunikacinių paslaugų kokybès vertinimo faktorinè analizè (tèvų požiūris)

$$
(\mathrm{N}=400 ; \mathrm{KMO}=0,95 ; \alpha=0,95)
$$

\begin{tabular}{|l|c|c|}
\hline Faktoriai & $\begin{array}{c}\text { Faktorinis } \\
\text { svoris (L) }\end{array}$ & $\begin{array}{c}\text { Aprašomoji } \\
\text { sklaida (\%) }\end{array}$ \\
\cline { 1 - 2 } Informacijos pateikimas apie vaiko ugdymą ir pasiekimus & 0,967 & \multirow{2}{*}{87,8} \\
\cline { 1 - 2 } Informacijos pateikimas apie ugdymo įstaigos veiklą & 0,967 & \\
\cline { 1 - 2 } Specialistų teikiama informacija & 0,947 & \\
\cline { 1 - 2 } Gebejjimas išklausyti tėvus & 0,862 & \\
\hline
\end{tabular}

Faktorinès analizės rezultatai rodo, jog tèvų nuomone, ugdymo įstaigoje kokybiškai teikiamos informacinès-komunikacinès paslaugos yra šios: informacijos pateikimas apie vaiko ugdymą ir pasiekimus $(\mathrm{L}=0,967)$, informacijos pateikimas apie ịstaigos veiklą $(\mathrm{L}=0,967)$, specialistų teikiama informacija $(\mathrm{L}=0,947)$ bei gebejjimas išklausyti tèvus $(\mathrm{L}=0,862)$.

Vertinant teikiamų kultūrinių-rekreacinių paslaugų kokybę tėvų požiūriu, faktorinès analizès pagrindinių komponenčių metodu buvo išskirtas vienas faktorius, apibūdinantis jų kokybę: kultūrinès-rekreacinés paslaugos (65,8 proc. atsakymų sklaidos) (žr. 5 lentelę).

Kultūrinių-rekreacinių paslaugų faktorius apima teiginius, kurie atspindi tèvų požiūriu ugdymo įstaigoje kokybiškai teikiamas tokias kultūrines-rekreacines paslaugas: renginių, švenčių organizavimas $(\mathrm{L}=0,821)$, išvykų, ekskursijų organizavimas $(\mathrm{L}=0,808)$ bei laisvalaikio organizavimas $(\mathrm{L}=0,804)$.

Pastaruoju metu itin daug dèmesio yra skiriama ugdymo institucijų gebejimams teikti ne tik švietimo, socialines, informacines, bet ir specialiosios pagalbos vaikui paslaugas. Specialiosios pagalbos paskirtis - nustatyti vaikų specialiuosius ugdymo(si) poreikius ir juos tenkinti, užtikrinti palankias jų ugdymo(si) sąlygas, stiprinti pedagogų, tèvų / globejjų gebejjimą ugdyti šiuos vaikus, didinant jų ugdymo(si) veiksmingumą. Specialiąją pagalbą ugdymo isstaigoje teikia medicinos darbuotojai, logopedas, specialusis pedagogas, tiflopedagogas, surdopedagogas, judesio korekcijos ir kiti specialistai tiems vaikams, kuriems jos reikia. 
6 lentele. Ugdymo ịstaigoje teikiamų kultūrinių-rekreacinių paslaugų kokybès vertinimo faktorinè analizè (tèvų požiūris)

$$
(\mathrm{N}=400 ; \mathrm{KMO}=0,78 ; \alpha=0,74)
$$

\begin{tabular}{|l|c|c|}
\hline Faktoriai & $\begin{array}{c}\text { Faktorinis svoris } \\
(\mathrm{L})\end{array}$ & $\begin{array}{c}\text { Aprašomoji } \\
\text { sklaida (\%) }\end{array}$ \\
\cline { 1 - 2 } Renginių, švenčių organizavimas & 0,821 & \multirow{2}{*}{65,8} \\
\cline { 1 - 2 } Išvykų, ekskursijų organizavimas & 0,808 & \\
\hline Laisvalaikio organizavimas & 0,804 & \\
\hline
\end{tabular}

Vertinant specialiosios pagalbos vaikui kokybę ugdymo ịstaigoje tėvų požiūriu, nagrinèta mokyklose dirbančių specialistų (medicinos darbuotojo, logopedo, psichologo, spec. pedagogo) veiklos kokybė. Faktorinès analizès pagrindinių komponenčių metodu buvo išskirtas vienas faktorius, apibūdinantis specialiosios pagalbos vaikui kokybę: specialistų teikiamų paslaugų kokybė (68,3 proc. atsakymų sklaidos). KMO $=0,79$ rodo, kad duomenys gerai tinka faktorinei analizei atlikti. Faktoriaus vidine konsistencija $\alpha=0,81$ rodo aukštą teiginių vidinį susietumą ir pažymi, kad teiginiai, sudarantys faktorių, yra homogeniški.

Apibendrinant ugdymo įstaigoje teikiamas paslaugas ir jų kokybę galima teigti, jog apibūdindami mokyklose teikiamų edukacinių paslaugų kokybės bruožus, tėvai labiausiai akcentuoja nepriekaištingą pedagogų pareigų atlikimą, veiklos atitikti numatytiems reikalavimams, žmogiškųjų ir materialiųjų išteklių racionalų valdymą, vartotojų poreikių ir lūkesčių patenkinimą bei nuolatinị ugdymo tobulinimą. Vertindami socialines paslaugas, tèvai kaip kokybiškiausias įvardija socialinę paramą ir vaiko priežiūrą, o informacineskomunikacines paslaugas - gebejjimą suteikti informaciją apie vaiko ugdymą, pasiekimus bei ugdymo įstaigos veiklą. Pasakytina tai, kad tėvai palankiai vertina ugdymo ịstaigoje teikiamas kultūrines-rekreacines paslaugas: renginių, švenčių, išvykų, ekskursijų bei laisvalaikio organizavimą. Vertindami specialistų teikiamų paslaugų ugdymo įstaigoje kokybę, tèvai akcentuoja medicinos darbuotojo, logopedo ir psichologo kokybiškai atliekamas veiklas.

\section{Išvados}

1. Švietimo politika tiesiogiai koreliuoja su valstybejje vysktančiais politiniais, socialiniais, ekonominiais pokyčiais. Šių pokyčių išdava - nuolatos papildomas edukacinių, socialinių ir švietimo pagalbos paslaugų sąrašas. Siekiama, kad vykdoma švietimo politika sudarytų kuo geresnes sąlygas mokinių švietimo prieinamumui, laiduotų kokybiškų edukacinių ir socialinių paslaugų teikimą, vartotojų (mokinių, tèvų) poreikių tenkinimą bei kokybišką ugdymo proceso organizavimą.

2. Ugdymo ịstaiga, siekdama teikti kokybiškas paslaugas, privalo identifikuoti skirtingus tèvų (grupinius ir individualius) poreikius, lūkesčius, dalyvavimo patirtị, vertybes bei ịtraukti juos ị ugdomosios veiklos ir įstaigos kūrimą, motyvuoti bendradarbiavimą su ugdymo paslaugų teikèjais. Bendradarbiavimo pagrindą sudaro susitarimas dèl ugdymo paslaugos kokybès požymių ir valdymo modeliavimo principų, todèl kad ugdymo paslau- 
ga ir jos produktas (ugdymo kokybė) priklauso nuo daugelio veiksnių (išorinių, vidinių), taip pat „kietųjų“/ materialiųjų ir „,minkštųjų“/ žmogiškųjų išteklių.

3. Kokybiškiausios edukacinès paslaugos bei kokybei būdingi bruožai yra nepriekaištingas pedagogų pareigų atlikimas, veiklos atitiktis numatytiems reikalavimams, žmogiškųjų ir materialiųjų išteklių racionalus valdymas, vartotojų poreikių ir lūkesčių patenkinimas bei nuolatinis ugdymo tobulinimas. Socialinés paslaugos - specialiųjų poreikių vaikų ugdymas, socialinès atskirties integracija, vaiko maitinimas, priežiūra ir globa; informacinès-komunikacinés paslaugos yra tèvams informacijos teikimas apie vaiko ugdymą, pasiekimus ir įstaigos veiklą; kultūrinès-rekreacines paslaugos - renginių, švenčių, išvykų, ekskursijų organizavimas vaikams; specializuotos pagalbos vaikams teikimo paslaugos yra medicinos darbuotojo, logopedo ir psichologo paslaugos.

4. Išryškejja sąveika ir cikliškumas tarp valstybès politikos, švietimo politikos bei kokybiškų paslaugų vartotojų tenkinimo. Valstybẻ formuodama švietimo politiką per švietimo institucijas jas ịpareigoja vykdyti kokybišką švietimo politikos ịgyvendinimą užtikrinant socialinių paslaugų teikimo efektyvumą. Siekdama nustatyti, ar švietimo politikos igyvendinimas atitinka vartotojų lūkesčius ir valstybès interesus bei ar švietimo pagalbos paslaugos pasiekia mokinį, kuriam jos reikalingos, valstybė atlieka stebėseną. Taip valstybė stebėsenos pagrindu pasitikrina švietimo politikos tikslingumą, efektyvumą ir remiantis stebésenos rezultatais yra kuriamos naujos švietimo strategijos, inicijuojamos reformos.

\section{Literatūra}

Andriekienè, R. M.; Trakšelys, K. Andragogical approaches of parental education in modern society. Journal of Modern Science. 2012, 3 (15): 127-140.

Andriekienè, R. M.; Anužienè, B. Andragoginiai kompetenciju tobulinimo aspektai tęstiniame profesiniame mokyme. Klaipèda: Klaipedos universiteto leidykla, 2006.

Bitinas, B. Pedagogines diagnostikos pagrindai. Vilnius: Vilniaus pedagoginio universiteto leidykla, 2002.

Bulajeva, T., et al. Lietuvos švietimo politikos transformacija. Vilnius: Vilniaus universiteto leidykla, 2009.

Chreptavičienė, V. Dalykinès komunikacijos raštu mokejimų samprata, lygiai. Edukologijos idejos Lietuvos švietimo sistemos modernizavimui (sudryt. P. Jucevičienè). Kaunas: Technologija, 1998.
Čekanavičius, V.; Murauskas, G. Statistika ir jos taikymai. II d. Vilnius: TEV, 2002.

Fullan, M. Innovation, Reform and Restructuring Strategies. Cawelti, G. ( ed) Challenges and Achievement of american Education. New York: ASCD, 1993.

Hargreaves, A.; Reynolds, D. Decomprehensivization. Hargreaves, A.; Reynolds, D. (eds) Education Policies: Controversies and Critiques. Philadelphia: The Falmer Press, 1989.

Išoraitè, M. Socialiniu paslaugu administravimas. Vilnius: Saulele, 2007.

Išoraite, M. Veiklos rezultatyvumo vertinimo ypatumai švietimo institucijose. Ekonomika ir vadyba: aktualijos ir perspektyvos. 2005, 5: 135-143.

Juodaitytè, A. Socialiniai-edukaciniai pokyčiai ikimokykliniame ugdyme: Rytu, Vidurio Europos šaliu, JAV ir Lietuvos patirties lyginamoji analize. Klaipèda: Klaipedos universitetas, 2000. 
Juodaitytè, A. Ikimokyklinio ugdymo sistemine kaita Europos Bendrijos ir pokomunistinèse šalyse. Acta Paedagogica Vilnensia. 2001, 8.

Kardelis, K. Moksliniu tyrimu metodologija ir metodai. Kaunas: Judex, 2002.

Mačerinskienè, I. Švietimo paslauga vartojimo ir investavimo ị žmogiškąji kapitalą aspektu. Edukologijos idejos Lietuvos švietimo sistemos modernizavimui (sudryt. P. Jucevičienè). Kaunas: Technologija, 1998.

Martišauskienė, D. Ikimokyklinio ugdymo paslaugu kokybès valdymo modeliavimas tiriant tèvu - vartotoju poreikius. Daktaro disertacija. Socialiniai mokslai (edukologija). Šiauliai: Liucilijus, 2010.

Merkys, G. Testavimas - socialinių mokslų principas. Metodologinio diskurso projekcija. Socialiniai mokslai. 1999, 2 (19): 7-22.

Rado, P. Transition in Education. Budapest: Society Institute, 2001.

Trowler, P. Education Policy. Second edition. London and New York: Routledge, 2003.
Trakšelys, K. Mokinių edukacinio stimulo deficitas. Tiltai. 2008, 2: 61-73.

Trakšelys, K. Pedagogų kvalifikacijos tobulinimas: profesionalizacijos elementas. Andragogika. 2011, 1: 38-45.

Trakšelys, K.; Martišauskienė, D. Pedagogų profesionalizacijos aspektai modernioje visuomeneje. Tiltai. 2013, 2 (63): 141-159.

Šimanskienè, L.; Trakšelys, K. Pedagoginès psichologinès pagalbos teikimas Lietuvos ir JAV švietimo sistemoje. Socialinis darbas. 2009, 8 (2).

Vaicekauskienè, V. Švietimo politikos analizès pagrindai. Vilnius: Švietimo ir mokslo ministerija, 2007.

Vaicekauskienė, V. Specialiuju poreikiu vaiku socializacija. Vilnius: Vilniaus universiteto leidykla, 2005.

Žalimienè, L. Socialinès paslaugos. Vilnius: Vilniaus universiteto Specialiosios psichologijos laboratorija, 2003.

Želvys, R. Švietimo sistemos tobulinimas gamintojai, vartotojai, teikejjai ir švietimo paslaugų kokybè. Acta Paedagogica Vilnensia. 2002, 9: 303-310.

\title{
CONNECTIONS OF EDUCATION POLICY, TRAINING QUALITY AND PROVIDED SERVICES OF USERS' NEEDS
}

\author{
Dalia Martišauskienė, Kęstutis Trakšelys \\ Klaipèda University, Lithuania
}

Summary. In the article, it is accented that the modern Lithuanian education policy requires guaranteeing a possibility for a child to use the services provided by the state and at the same time, it enables education institutions to create more various education and social service forms, meeting children/youth needs. It is noted that the aim of the activities of education institutions, as of other organizations, is the provision of users' needs. This is why it so important to understand that users of services are the most important people, because the users do not depend on the institution, but the institution depends on them. The opinion is presented that a child is the user of education institution, his/her parents or, in other words, family, which can orient the child's behavior according to religion, politics, 
economics, personal ambitions, etc. In the article, the problem is analysed that until now in Lithuania there has been a lack of consensus among the formed state, regional education policy, provided service quality and provision of users' needs to guarantee a possibility for a child to use the services provided by the state, giving as many various education services as possible, meeting child/youth needs, and constantly seeking for the quality of educational, social and other services.

The main information sources of the empirical research have been parents of Klaipeda region, whose children attend education institutions. The results of the empirical research revealed that education institution, aiming to provide the quality of services, has to identify different parents' (group and individual) needs, expectations, experience of attendance, values, and to involve them into creation of educational activities and institution, motivate collaboration with providers of education services. Also, the article provides the general respondents' opinion about the features specific for the education quality, provided educational, social and other quality of services and agreement with the formed state education policy.

Keywords: education policy, education quality, service users' needs.

Dalia Martišauskienė, Klaipėdos universiteto Sveikatos mokslų fakulteto Visuomenės sveikatos katedros docentè, socialinių mokslų daktarè (edukologija). Mokslinių tyrimų kryptys: švietimo vadyba, kokybės vadyba, edukologija, andragogika.

Kęstutis Trakšelys, Klaipėdos universiteto Tęstinių studijų instituto mokslo darbuotojas, doktorantas. Mokslinių tyrimų kryptys: švietimo sociologija, švietimo politika, suaugusiųjų švietimas.

Dalia Martišauskienė, Doctor of Social Sciences (Educology), Klaipėda University, Faculty of Health Sciences, Department of Public Health, Associate Professor. Research interests: education management, quality management, education, andragogy.

Kęstutis Trakšelys, Klaipèda University, Department of Institute of Continuing Studies, Researcher of Andragogy. Research interests: sociology of education. 